\title{
Persepsi Mahasiswa Pendidikan Matematika TeRhadaP PERKuliahan ONLINE
}

\author{
Erin1, Anggita Maharani²* \\ 1Pendidikan Matematika, Universitas Swadaya Gunung Djati (UNSWAGATI) \\ Jl. Perjuangan, Cirebon \\ erin43544@gmail.com \\ ${ }^{2}$ Pendidikan Matematika, Universitas Swadaya Gunung Djati (UNSWAGATI) \\ Jl. Perjuangan, Cirebon \\ anggi3007@yahoo.co.id@yahoo.co.id
}

Artikel diterima: 26 Mei 2018, direvisi: 5 September 2018, diterbitkan: 30 September 2018

\begin{abstract}
Abstrak
Artikel ini membahas mengenai hasil penelitian yang bertujuan untuk mengetahui persepsi mahasiswa pendidikan matematika terhadap pelaksanaan perkuliahan online menggunakan aplikasi Edmodo. Penelitian ini menggunakan pendekatan kualitatif. Penelitian deskriptif studi kasus ini melibatkan 80 subjek penelitian yang merupakan mahasiswa Pendidikan Matematika Tingkat 3 pada salah satu Perguruan Tinggi swasta di Cirebon Tahun Akademik 2015/2016. Hasil penelitian ini diperoleh melalui lembar angket, wawancara, dan observasi. Analisis data berfokus pada Seleksi, Interpretasi dan Reaksi mahasiswa. Hasil angket menunjukkan terdapat $85 \%$ mahasiswa cenderung pada pernyataan positif sedangkan yang cenderung pada pernyataan negatif hanya $25 \%$. Hasil triangulasi data dari penyebaran angket, wawancara dan observasi dapat diketahui bahwa rata-rata dari mahasiswa menyukai perkuliahan online dan mahasiswa sudah mengetahui dan bisa menggunakan aplikasi yang mendukung perkuliahan online seperti Edmodo. Menurut mahasiswa, perkuliahan online sangat nyaman dan efektif ketika mahasiswa mendapatkan jaringan internet yang baik. Akan tetapi, mahasiswa merasa perlu mendapat perkuliahan konvensional (tatap muka) untuk meyakinkan pemahaman mereka.

Kata Kunci: persepsi, perkuliahan Online, Edmodo
\end{abstract}

\begin{abstract}
Mathematical Education Students' Perception on Online Course) This article discusses the results of research that aims to determine the perception of mathematics education students to the implementation of online lectures using Edmodo application. This research uses qualitative approach. This descriptive case study research involves 80 research subjects who are students of Mathematics Education Level 3 at one private university in Cirebon Academic Year 2015/2016. The results of this study were obtained through questionnaires, interviews, and observations. Data analysis focuses on Student Selection, Interpretation and Reaction. The questionnaire results show that $85 \%$ of students tend to be positive statements, while those that tend to negative statements are only 25\%. Triangulation of data from questionnaires, interviews and observations can be seen that the average of the students liked the lectures online and students already know and can use applications that support online lectures such as Edmodo. According to students, online lectures are very convenient and effective when students get a good internet network. However, students feel the need to get a conventional lecture (face-to-face) to convince their understanding.

Keywords: perception, Online lecture, Edmodo
\end{abstract}


http://journal.institutpendidikan.ac.id/index.php/mosharafa

\section{Pendahuluan}

Perkuliahan online adalah salah proses pembelajaran yang interaktif, antara dosen dan mahasiswa melalui media sosial. Dalam perkuliahan online ini, dosen dan mahasiswa tidak bertatap muka secara langsung. Bagi mahasiswa yang bekerja atau yang berwirausaha, dengan adanya kuliah online ini dapat menjadi solusi dan sangat membantu mereka untuk mengikuti kelas perkuliahan. Seperti halnya penelitian yang dilakukan (Sukarno, 2014) perkuliahan online memudahkan dosen dalam melaksanakan tugasnya seperti pemberian pemberian materi (mengungahnya), memberi tugas dan mengadakan ujian/kuis. Perkuliahan online juga dapat mendorong mahasiswa untuk lebih kreatif, mandiri dan disiplin dalam belajar. Karena biasanya dalam perkuliahan online ini ditentukan waktunya sesuai dengan kesepakatan antara dosen dan mahasiswa.

Pelaksanaan kuliah online dinilai sangat efektif. Di tengah laju perkembangan teknologi saat ini, perkuliahan online dapat dianggap sebagai solusi pembelajaran dalam rangka mengembangkan kreativitas mahasiswa. Kemudahan dalam menggunakan berbagai macam alat teknologi komunikasi seperti smartphone, gadget, tablet ataupun komputer menambah berbagai alasan positif mengapa perkuliahan online efektif dilakukan di perguruan tinggi.

Salah satu aplikasi yang dapat menunjang perkuliahan online adalah Edmodo. Edmodo adalah suatu alat komunikasi, kolaborasi dan pembinaan dalam dunia pendidikan. Edmodo merupakan aplikasi pembelajaran yang dapat diperoleh secara gratis untuk digunakan oleh guru dalam mengelola pembelajaran online. Edmodo memungkinkan siswa terhubung dengan gurunya dimana saja dan kapan saja
(Balasubramanian, Jaykumar, \& Fukey, 2014). Aplikasi edmodo menurut Pitoy (Kurniasih, Sujadi, \& Subanti, 2016) merupakan platform social network yang dapat menunjang dosen dapat mengadakan kuis, tugas dan mengelola komunikasi dengan mahasiswanya. Aplikasi ini sangat bagus untuk dosen yang mempunyai jadwal yang padat, sehingga interaksi maupun proses belajar-mengajar dapat terlaksana. Seperti dilansir oleh (Kurniasih et al., 2016) bahwa edmodo memiliki fitur mirip facebook yang memungkinkan terjadinya interaksi antara dosen, mahasiswa, bahkan orangtua.

Kuliah online merupakan perkuliahan yang dilakukan secara online. Perkuliahan online difasilitasi oleh adanya teknologi informasi. Tujuan adanya kuliah online adalah menciptakan proses belajar-mengajar antara dosen dan mahasiswa yang lebih praktis, dimana dosen dan mahasiswa dapat melaksanakan perkuliahan dimanapun tanpa kenal jarak, memberikan kesempatan untuk mahasiswa yang tidak hadir saat perkuliahan secara konvensional, menjadikan mahasiswa lebih mengenal TIK (Teknologi, Informasi dan Komunikasi), menjadikan mahasiswa lebih mandiri dalam belajar dan memahami informasi yang diberikan oleh dosen, serta memudahkan mahasiswa untuk berinteraksi dengan dosen mengenai materi yang kurang dipahami oleh mahasiswa tersebut. Kecenderungan mahasiswa ketika belajar tatap muka, seperti: malu bertanya ataupun rasa takut keliru dalam menjawab pertanyaan (Afriansyah, 2017), dapat teratasi dengan perkuliahan online.

Sistem kuliahan online dengan menggunakan media internet disebut dengan istilah e-learning. Pelaksanaan kuliah online, setidaknya dapat dilakukan melalui 3 cara yakni melalui program khusus kuliah online, 
kuliah online sebagai pendukung kuliah tatap muka, dan kuliah online nongelar.

Bagi perguruan tinggi yang melaksanakan program khusus kuliah online, mahasiswa memiliki ruang untuk menjalani kuliah secara fleksibel, kapan saja, dan dimana saja. Seluruh rangkaian perkuliahan seperti pemberian materi, kuis, tugas, dan absensi dapat diakses secara online. Dosen dapat menyiapkan materi perkuliahan dan menayangkannya via internet sehingga mahasiswa dapat menyimak penjelasan dosen melalui alat komunikasinya masing-masing. Pada perkuliahan yang menggunakan program khusus online, terdapat tiga chatroom berbeda sebagai media untuk berdiskusi dengan dosen ataupun diskusi kelompok. Program khusus online juga dapat dilakukan secara real time, yakni kuliah secara langsung (live) melalui perantara internet.

Kuliah online dilakukan sebagai pendukung kuliah tatap muka dengan memanfaatkan teknologi komunikasi untuk meningkatkan kualitas perkuliahan. Kuliah online tipe ini memungkinkan dosen untuk memberikan materi perkuliahannya dalam bentuk modul mauun soal yang dpat diakses mahasiswa secara online. Dosen hanya perlu mengunggah materi untuk kemudian diunduh oleh mahasiswa. Karena sifatnya hanya sebagia pendukung, dosen dapat menentukan waktu tatap muka sesuai kesepakatan dengan mahasiswanya.

Kuliah online non gelar kini banyak tersedia dan dapat diakses oleh siapapun melalui internet. Dalam satu waktu, terdapat sekelompok orang (mahasiswa) yang bersama-sama belajar melalui tayangan video, tutorial, maupun tugas. Untuk dapat mengikuti kuliah online non gelar, caranya mudah saja yakni registrasi. Kalau sudah terdaftar, selanjutnya peserta kuliah mendapat jadual kuliah.

Tujuan dari pelaksanaan e-learning tidaklah berbeda dengan tujuan pembeajaran langsung (tatap muka). Berdasarkan peraturan pemerintah nomor 109 tahun 2013 tentang penyelenggaraan Pendidikan Jarak Jauh pada pendidikan tinggi menjelaskan bahwa tujuan pencapaian pembelajaran PJJ (Pendidikan Jarak Jauh) harus sama dengan tujuan pencapaian pembelajaran pada sistem tatap muka. Tujuan pembelajaran dinyatakan tercapai apabila mahasiswa memahami dan mengerti apa yang disampaikan oleh dosen dan dapat mengaplikasikan materi dalam kehidupan sehari-hari.

$\mathrm{Hal}$ ini sangat berbeda dengan kenyataannya. Faktanya banyak masalahmasalah yang muncul setelah peraturan pemerintah tersebut diberlakukan. Dari masalah tentang kesalahpahaman materi dan pemahaman konsep sampai ketidakpahaman mahasiswa dalam menggunakan aplikasi yang menunjang perkuliahan online (misalnya, Edmodo). Hal inilah yang membuat kuliah tatap muka tidak dapat tergantikan.

Hal tersebut yang dirasakan oleh mahasiswa jurusan pendidikan matematika pada salah satu perguruan tinggi swasta di Cirebon. Pada jurusan pendidikan matematika, pembelajarannya tidak hanya mempelajari tentang pengelolaan kelas, metode pembelajaran, model pembelajaran dan yang berkaitan dengan pendidikan. Tetapi juga lebih ditekankan untuk mengerti dan memahami konsep dan lambang matematika. Secara logika, perkuliahan secara online akan menyulitkan proses belajar mahasiswa. Mahasiswa kurang memahami materi yang diberikan oleh dosen dalam aplikasi edmodo. Ketidaklengkapan tentang pembahasan materi 
http://journal.institutpendidikan.ac.id/index.php/mosharafa

serta gaya bahasa dosen yang terlalu tinggi adalah akar dari permasalahannya.

Beberapa penelitian telah menunjukkan dampak positif dari penggunaan edmodo. Implementasi edmodo yang dikolaburasikan dengan model PBL dan pendekatan PMRI memberikan dampak terhadap peningkatan kemampuan literasi matematis (Waluya \& Mariani, 2016). Hasil penelitiannya juga menunjukkan bahwa penggunaan edmodo memberikan kualitas yang sangat baik pada proses pembelajaran. Di Filipina, edmodo telah digunakan sebagai alat tambahan untuk belajar pada ilmu sosial. Data hasil penelitian (Enriquez, 2014) menunjukkan bahwa mahasiswa pengguna edmodo menyatakan bahwa edmodo merupakan alat tambahan yang efektif untuk membantu pembelajaran mereka.

Kajian lain mengenai efektifitas edmodo juga menunjukkan bahwa efektif baik dari aspek usefulness, ease of use, ease of learning, maupun satisfaction (Sa'diyah, Utami, \& Tianisa, 2018). Dengan demikian, efektifitas penggunaan edmodo masih belum dapat dikatakan efektif untuk meningkatkan prestasi belajar.

Mengetahui persepsi mengenai pembelajaran yang telah dilakukan seorang dosen, sangatlah penting sebagai pijakan untuk mengambil langkah berikutnya. Hasil penelitian menunjukkan bahwa motivasi berprestasi dan persepsi yang dimiliki siswa berkenaan dengan cara guru mengajar, akan berpengaruh signifikan terhadap hasil belajar matematika. Persepsi yang positif akan berhubungan secara linier positif terhadap pencapaian hasil dan sikap positif mampu mendorong motivasi belajar. Lebih lanjut hasil penelitiannya mengungkapkan bahwa persepsi yang baik terhadap metode mengajar menunjukkan rerata skor yang tinggi dalam matematika (Sahidin \& Jamil, 2013; Wardana \& Damayani, 2017).

Persepsi merupakan tanggapan yang dimiliki oleh setiap individu melalui proses pengindraanya. Persepsi muncul berdasarkan pengalaman dan perasaannya. Proses psikologis melalui pengalaman yang diperoleh panca indranya, individu dapat mengolah respons menjadi persepsi positif atau negatif. Perolehan respon didapat melalui tahapan seleksi, intepretasi, dan reaksi.

Ketika panca indra mendapatkan stimulus, selanjutnya individu akan melakukan seleksi. Pemilihan stimulus akan bergantung pada individu masing-masing termasuk cara pandangnya. Untuk itulah, agar muncul persepsi maka sangat penting memberi stimulus yang tepat sesuai dengan karakter individu. Individu selanjutnya mengintepretasikan stimulus yang terseleksi sesuai dengan pengetahuan, pengalaman, kecerdasan, nilai-nilai serta keyakinan yang dimilikinya. Intepretasi dilakukan untuk mereduksi informasi kompleks yang diperolehnya menjadi lebih sederhana. Hasil dari intepretasi adalah reaksi.

Reaksi positif berdasarkan persepsi positif. Jika individu merasa bahwa informasi atau stimulus yang diterimanya bermanfaat dan menyenangkan bagi dirinya, maka individu akan menilai segala yang berkaitan dengan stimulus itu dengan positif. Demikian sebaliknya, penilaian negatif akan muncul jika individu menilai stimulus yang diterimanya tidak berguna (Winkel, 1996).

Pembelajaran online yang dilakukan di FKIP pada salah satu perguruan tinggi swasta di Cirebon, diantaranya telah diterapkan pada mata kuliah ajabar abstrak. sebagai dosen pengajar, tentunya telah memparhatikan 
beberapa hal menganai pembelajaran online, sebelum pembelajaran dimulai. Pembelajaran online atau disebut juga dengan web-based learning haruslah memperhatikan berbagai karakter pengguna (Prawiradilaga, 2015). Dengan demikian, rancangan pembelajaran online yang dibuat oleh dosen haruslah mampu mengakomodir seluruh kebutuhan pengguna dalam hal ini mahasiswa. Ketika akan merancang sebuah pembelajaran online, dosen juga hendaknya memperhatikan apakah seluruh mahasiswa dapat mengakses materi sesuai dengan tujuan pembalajaran yang telah ditetapkannya? Pertimbangan yang diambil dosen sebelum memutuskan pembelajaran online, akan sangat berpengaruh terhadap persepsi mahasiswa terhadap keterlaksanaan pembelajaran online tersebut.

Artikel ini akan menguraikan hasil penelitian yang membahas mengenai persepsi mahasiswa pendidikan matematika terhadap perkuliahan online yang telah diterapkan pada FKIP Program Studi Matematika pada salah satu perguruan tinggi swasta di Cirebon.

\section{Metode}

Penelitian ini menggunakan pendekatan kualitatif yang bertujuan untuk mengetahui dan melihat kondisi yang alami dari suatu fenomena. Penelitian ini bertujuan untuk memperoleh gambaran kondisi yang sebenarnya. Penelitian kualitatif merupakan penelitian yang mengandung penelitian deskriptif. Artinya, penelitian yang hanya terbatas pada usaha mengungkapkan suatu masalah dan keadaan sebagaimana adanya, sehingga hanya sekedar mengungkapkan fakta. Pengguna penelitian kualitatif di Indonesia khususnya di bidang pendidikan matematika masih sangat jarang (Afriansyah, 2016).
Metode penelitian ini tergolong penelitian deskriptif, yaitu penelitian yang hanya terbatas pada usaha mengungkapkan suatu masalah dan keadaan sebagaimana adanya, sehingga hanya sekedar mengungkapkan fakta. Penelitian melibatkan 80 subjek penelitian yang merupakan mahasiswa Pendidikan Matematika Tingkat 3 pada salah satu Perguruan Tinggi swasta di Cirebon Tahun Akademik 2015/2016. Jenis penelitian deskriptif yang digunakan penulis adalah studi kasus, yaitu jenis penelitian tentang subyek tertentu dimana subyek tersebut terbatas, maka kesimpulan yang diperoleh hanya terbatas pada subyek yang dimiliki. Dengan prosedur yang akan diambil yaitu mula-mula pemberian angket kepada subjek yang akan diteliti. Setelah data terkumpulkan, peneliti mewawancarai beberapa mahasiswa mengenai perkuliahan online.

Pemberian angket dan wawancara adalah untuk mengetahui persepsi setiap responden terhadap perkuliahan online karena setiap mahasiswa pastilah memiliki pendapat maupun persepsi yang berbeda-beda. Langkah selanjutnya adalah melakukan observasi terkait perkuliahan online dan membandingkan antara data yang sudah tekumpulkan dengan keadaan observasi.

Untuk mengetahui sejauhmana informasi yang diberikan oleh responden, peneliti melakukan beberapa tahap:

1. Membuat dan menyusun sebuah pernyataan berdasarkan komponenkomponen persepsi untuk lembaran angket.

2. Menyebarkan angket kepada responden (tingkat 3 pendidikan matematika FKIP).

3. Membuat draf pertanyaan untuk koresponden. 
http://journal.institutpendidikan.ac.id/index.php/mosharafa

4. Melakukan wawancara dan dokumentasi langsung dengan koresponden.

5. Menganalisis data dari hasil lembaran angket dan wawancara.

Dengan menggunakan skala likert, berikut ini adalah angket yang digunakan peneliti sebagai instrumen penelitian untuk mengetahui persepsi mahasiswa terhadap pelaksanaan pembelajaran kuliah online.

Tabel 1

Instrumen Pernyataan Angket

\begin{tabular}{|c|c|}
\hline No & Pernyataan \\
\hline 1. & Saya pernah mendengar perkuliahan online \\
\hline 2. & $\begin{array}{l}\text { Saya merasa yakin perkuliahan online sangat } \\
\text { baik diadakan pada seluruh mata kuliah di } \\
\text { prodi pendidikan Matematika }\end{array}$ \\
\hline 3. & Saya pernah mengikuti perkuliahan online \\
\hline 4. & $\begin{array}{l}\text { Saya merasa nyaman mengikuti perkuliahan } \\
\text { online dari pada perkuliahan konvensional }\end{array}$ \\
\hline 5. & $\begin{array}{l}\text { Saya tidak memahami sama sekali materi saat } \\
\text { perkuliahan online berlangsung }\end{array}$ \\
\hline 6. & $\begin{array}{l}\text { Saya bisa menggunakan aplikasi yang } \\
\text { menunjang perkuliahan online ( seperti } \\
\text { edmodo) }\end{array}$ \\
\hline 7. & $\begin{array}{l}\text { Saya lebih nyaman mengikuti perkuliahan } \\
\text { konvensional dari pada perkuliahan online }\end{array}$ \\
\hline 8. & $\begin{array}{l}\text { Saya merasa yakin perkuliahan online dapat } \\
\text { menunjang keterlambatan mata kuliah }\end{array}$ \\
\hline 9. & $\begin{array}{l}\text { Saya memahami materi perkuliahan saat } \\
\text { perkuliahan online }\end{array}$ \\
\hline 10. & $\begin{array}{l}\text { Saya merasa dengan adanya perkuliahan } \\
\text { online nilai mata kuliah saya menurun }\end{array}$ \\
\hline 11. & $\begin{array}{l}\text { Saya merasa perkuliahan online akan baik jika } \\
\text { dilaksanakan hanya sesekali saja }\end{array}$ \\
\hline 12. & $\begin{array}{l}\text { Saya merasa dengan adanya perkuliahan } \\
\text { online nilai mata kuliah saya meningkat }\end{array}$ \\
\hline 13. & $\begin{array}{l}\text { Saya merasa perkuliahan online tidak objektif } \\
\text { ditempatkan pada mata kuliah di prodi } \\
\text { pendidikan matematika }\end{array}$ \\
\hline 14. & $\begin{array}{l}\text { Saya merasa materi yang diberikan dosen saat } \\
\text { perkuliahan online lebih detail dan dapat } \\
\text { berpikir kritis. }\end{array}$ \\
\hline
\end{tabular}

\section{Hasil dan Pembahasan}

Hasil penelitian diperoleh dengan teknik triangulasi yakni menggunakan pendekatan multimetode sehingga memperoleh kebenaran tingkat tinggi jika ditunjau dari berbagai sudut pandang (Rahardjo, 2010). Pernyataan dalam angket maupun wawancara adalah mengenai interpretasi, reaksi, dan seleksi mahasiswa pendidikan matematika terhadap perkuliahan online untuk mengetahui persepsi mahasiswa. Lembar angket dan wawancara dengan responden secara langsung. Ketika datanya sudah terkumpul kemudian dianalisis. Analisis di sini berfokus pada seleksi, interpretasi dan reaksi mahasiswa.

Pengambilan data dilakukan dalam kurun waktu kurang dari 1 minggu yakni penyebaran lembar angket kepada responden dilakukan pada tanggal 27 Desember 2017. Sedangkan wawancara dilakukan pada tanggal 30 Desember 2017. Dari hasil penyebaran angket ini didapat bahwa dari pernyataan positif dan negatif yang terdapat pada angket yaitu $85 \%$ mahasiswa cenderung kepada pernyataan yang positif dan hanya $25 \%$ mahasiswa cenderung menyetujui pernyataan negatif. Jadi, rata-rata dari mahasiswa menyukai perkuliahan online dan mahasiswa sudah mengetahui dan dapat menggunakan aplikasi yang mendukung perkuliahan online.

Dari hasil wawancara, rata-rata mahasiswa mengatakan bahwa perkuliahan online sangat efektif karena mahasiswa bisa belajar dimana aja tidak hanya dikampus tapi bisa dirumah juga. Perkuliahan online dirasakan sangat nyaman, yang penting sinyal bagus. Kelebihannya dari kuliah online, jika mahasiswa tidak bisa kuliah dikampus maka mereka tetap dapat belajar di rumah. Kekurangannya jika kita kuotanya abis dan sinyal jelek, kita tidak bisa mengikuti perkuliahan online.

Kesannya yang muncul setelah mengikuti pembelajaran dengan metode perkuliahan online adalah menyenangkan. Sarannya yaitu 
kalau kuliah online jangan hanya tugas-tugas tapi bisa ada video interaktifnya. Sistem perkuliahan online yang selama ini berlangsung hanya meliputi penyelesaian tugas yang kemudian harus di upload via aplikasi, jadi rata-rata hanya mengerjakan tugas-tugas saja. Perkuliahan online menggunakan aplikasi edmodo. Perbedaan antara perkuliahan online dan perkuliahan konvensional. Perasaan saya ketika mengikuti perkuliahan online itu menyenangkan, sedangkan mengikuti perkuliahan konvensional itu membuat menegangkan.

Hal tersebut sama dengan komponenkomponen persepsi yaitu seleksi, interpretasi dan reaksi mahasiswa pendidikan matematika terhadap perkuliahan online.

\section{Penutup}

Berdasarkan hasil penelitian dan pengolahan data yang sudah dilakukan, maka dapat ditarik kesimpulan yaitu: 1) Mahasiswa pendidikan matematika menyukai perkuliahan online meskipun diadakan hanya sesekali saja; 2) Mahasiswa sudah bisa menggunakan salah satu aplikasi yang menunjang perkuliahan online, yaitu edmodo; dan 3) Dari hasil penyebaran angket dan wawancara menunjukkan bahwa mahasiswa nyaman melakukan perkuliahan online ketika kuota dan jaringan internet penuh.

Beberapa saran yang dapat diberikan adalah: 1) Perkuliahan online diadakan hanya sesekali saja sebab perkuliahan konvensional dapat menunjang pemahaman mahasiswa terhadap matakuliah akan tinggi; dan 2) Materi dan waktu pelaksanaan perkuliahan online harus jelas.

\section{Daftar Pustaka}

Afriansyah, E. A. (2016). Penggunaan Software
ATLAS.ti sebagai Alat Bantu Proses Analisis Data Kualitatif. Mosharafa: Jurnal Pendidikan Matematika, 5(2), 53-63.

Afriansyah, E. A. (2017). Desain Lintasan Pembelajaran Pecahan melalui Pendekatan Realistic Mathematics Education. Mosharafa: Jurnal Pendidikan Matematika, 6(3), 463-474.

Balasubramanian, K., Jaykumar, V., \& Fukey, L. N. (2014). A study on "Student preference towards the use of Edmodo as a learning platform to create responsible learning environment." Procedia-Social and Behavioral Sciences, 144, 416-422.

Enriquez, M. A. S. (2014). Students' Perceptions on the Effectiveness of the Use of Edmodo as a Supplementary Tool for Learning. In DLSU Research Congress (pp. 1-6).

Kurniasih, R., Sujadi, I., \& Subanti, S. (2016). Pengembangan Bahan Ajar Dengan Edmodo Untuk Meningkatkan Level Berpikir Probabilistik Siswa Kelas Viii Smp Negeri 12 Surakarta. Jurnal Elektrik Pembelajaran Matematika, 4(10), 961972.

Prawiradilaga, D. S. (2015). Prinsip desain pembelajaran. Kencana.

Rahardjo, M. (2010). Triangulasi dalam penelitian kualitatif.

Sa'diyah, H., Utami, T. S., \& Tianisa, W. T. (2018). Pengembangan Media E-Learning Berbasis Edmodo pada Mata Pelajaran Matematika Kelas VII di SMP Muhammadiyah 3 Depok. Dalam Seminar Nasional Pendidikan Matematika Ahmad Dahlan (Vol. 1, pp. 84-87).

Sahidin, L., \& Jamil, D. (2013). Pengaruh motivasi berprestasi dan persepsi siswa tentang cara guru mengajar terhadap hasil belajar matematika. Jurnal Pendidikan Matematika, 4(2), 212-222.

Sukarno. (2014). Peningkatan Kualitas Perkuliahan Melalui Penerapan Model Blended Learning Dengan Aplikasi Learning Management System Pada 
Mahasiswa

Program

Sarjana

Kependidikan Bagi Guru Dalam Jabatan. Jurnal Pendidikan Dan Pembelajaran, 21, 61-70.

Waluya, S. B., \& Mariani, S. (2016). Mathematics Literacy on Problem Based Learning with Indonesian Realistic Mathematics Education Approach Assisted E-Learning Edmodo. In Journal of Physics: Conference Series (Vol. 693, p. 12014). IOP Publishing.

Wardana, M. Y. S., \& Damayani, A. T. (2017). PERSEPSI SISWA TERHADAP PEMBELAJARAN PECAHAN DI SEKOLAH DASAR. Mosharafa: Jurnal Pendidikan Matematika, 6(3), 451-462. Retrieved from http://emosharafa.org/index.php/mosharafa/arti cle/view/mv6n3_14/136

Winkel, W. S. (1996). Psikologi Pengajaran, Edisi yang Disempurnakan, Cetakan ke-4. Jakarta Grasindo. 